\title{
Accurate Measurement of 8-OH-dG and 8-OH-Gua in Mouse DNA, Urine and Serum: Effects of $X$-ray Irradiation
}

\author{
Kazuaki Kawai, Yun-Shan Li and Hiroshi Kasai ${ }^{1}$ \\ Department of Environmental Oncology, Institute of Industrial Ecological Sciences, University of Occupational and \\ Environmental Health, Fukuoka, Japan
}

(Received May 21, 2007; Revised June 22, 2007; Accepted June 25, 2007)

\begin{abstract}
Oxidative stress is believed to increase the risk of lifestyle-related diseases, such as cancer and heart disease. For the measurement of oxidative stress in vivo, 8-hydroxydeoxyguanosine (8-OH-dG) in DNA or urine is the most popular biomarker. However, there are some difficulties in the reproducible and accurate analysis of 8-OH-dG in DNA. In this study, we found that artifactual 8-OH-dG was elevated significantly with time in an analytical sample kept at $10^{\circ} \mathrm{C}$, but not for one kept at $-80^{\circ} \mathrm{C}$. Furthermore, we developed a method for urinary 8-OH-dG analysis with high accuracy by an HPLC-ECD system, using anion-exchange- and reverse-phase-columns. This method can also be used for urinary and serum 8-hydroxyguanine (8-OH-Gua, free base) analyses, with a slight modification. By applying these improved methods, we confirmed the induction of oxidative stress with low dose ( $2 \mathrm{~Gy}$ ) whole body $\mathrm{X}$-ray irradiation of mice. The $8-\mathrm{OH}-\mathrm{dG}$ levels in the mouse urine were increased about 4.2-fold by $2 \mathrm{~Gy}$ irradiation, in a dose-dependent manner. The 8-OHGua levels in the serum were also increased with $2 \mathrm{~Gy}$ of irradiation. These results suggest that our improved $8-\mathrm{OH}$ dG and 8-OH-Gua analysis methods are useful for measurements of oxidative stress in vivo.
\end{abstract}

Key words: 8-hydroxydeoxyguanosine, 8-hydroxyguanine, oxidative stress, X-ray irradiation

\section{Introduction}

8-Hydroxydeoxyguanosine (1) $(8-\mathrm{OH}-\mathrm{dG})$ is one of the major forms of oxidative DNA damage, and has been well studied because it is relatively easy to detect, by using an HPLC-ECD system. To investigate the role of oxidative stress in carcinogenesis, it is important to measure the 8-OH-dG levels accurately in cellular DNA and biological fluids, such as urine and serum. Although many improvements have been made in DNA isolation and digestion methods, to prevent the artificial formation of $8-\mathrm{OH}-\mathrm{dG}$, there are still some difficulties in the reproducible analysis of $8-\mathrm{OH}-\mathrm{dG}$ in cellular DNA.

Urinary $8-\mathrm{OH}-\mathrm{dG}$ (2) is often used as an in vivo marker of oxidative stress in human studies and animal experiments. More than 600 papers have been published on urinary $8-\mathrm{OH}-\mathrm{dG}$ analysis. In most of these studies, the $8-\mathrm{OH}-\mathrm{dG}$ was analyzed by the enzyme-linked immunosorbent assay (ELISA) method (3). Recently, a discrepancy between the data obtained by the LC-MSMS and ELISA methods was pointed out (4). The urinary 8-OH-dG levels measured by the ELISA method were at least 2-3 times higher than those obtained by the HPLC-ECD or the LC-MS-MS method $(5,6)$, probably because the commercial monoclonal antibody may cross-react with other components in urine. In addition, the reproducibility of the analyses by ELISA method was very low (7). We developed an automatic method for urinary $8-\mathrm{OH}-\mathrm{dG}$ analysis with high accuracy by HPLC-ECD, using anion-exchange- and reverse phasecolumns. This method can also be used for urinary and serum 8-OH-Guanine (8-OH-Gua) analyses with a slight modification.

The urinary excretion of $8-\mathrm{OH}-\mathrm{Gua}$ is reportedly affected by the diet (8). High urinary 8-OH-Gua levels were detected when a standard commercial diet was orally administered to mice, but their levels were reduced by changing the diet to a nucleic-acid-free diet. In addition, 8-OH-Gua cannot be detected by the ELISA method. 8-OH-Gua can only be analyzed by a more complicated method, namely, HPLC-ECD after pre-purification with an 8-OH-dG antibody-bound affinity column (8), or GC-MS after HPLC pre-purification (9). These extra steps interfere with the general use of urinary 8-OH-Gua as a marker of oxidative stress. In this study, we established the optimal conditions for animal experiments to reduce the background levels of 8-OH-Gua and 8-OH-dG. Using these conditions, the oxidative stress induced by X-ray irradiation of mice was correctly assessed.

${ }^{1}$ Correspondence to: Hiroshi Kasai, Department of Environmental Oncology, Institute of Industrial Ecological Sciences, University of Occupational and Environmental Health, 1-1 Iseigaoka, Yahatanishiku, Kitakyushu, Fukuoka 807-8555, Japan. Tel: +81-93-691-7468, Fax: +81-93-601-2199, E-mail : h-kasai@med.uoeh-u.ac.jp 


\section{Materials and Methods}

Chemicals: The $8-\mathrm{OH}-\mathrm{dG}$ and $8-\mathrm{OH}-\mathrm{Gua}$, as authentic standards, were obtained from Sigma Chemical Co. (St. Louis, MO, USA) and Aldrich (Milwaukee, WI, USA), respectively. 8-Hydroxyguanosine $(8-\mathrm{OH}-$ Guo) was prepared by the method of Ikehara et al. (10). 2-Acetamide-6-hydroxypurine ( $N^{2}$-acetylguanine, AcG) was purchased from Tokyo Kasei Kogyo Co. (Tokyo, Japan). It was used after recrystallization.

Animals: Five-week-old female ICR mice and 7week-old female C57BL/6J mice were obtained from SLC Japan Inc. (Shizuoka, Japan). Animals were ad libitum fed a diet containing egg white as the protein source (Egg white diet; Dyets no. 110952; Dyets Inc., Bethlehem, PA, USA), which has a lower level of 8-OHGua and $8-\mathrm{OH}-\mathrm{dG}$, and were maintained in a temperature- and photoperiod (12h/day)-controlled room. To study the urinary levels of $8-\mathrm{OH}-\mathrm{Gua}$ compounds after their administration, ICR mice (7 weeks of age) were used. C57BL/6L mice (8 weeks of age) were used for other experiments. All of the animal experimental procedures were carried out in accordance with the guidelines for the care and use of laboratory animals at the University of Occupational and Environmental Health, Japan.

Administration of 8-OH-Gua-related compounds to mice: To study the effect of the oral intake of $8-\mathrm{OH}-$ $\mathrm{dG}, 8-\mathrm{OH}-\mathrm{Guo}$ or 8-OH-Gua on the urinary levels of these compounds, these compounds were mixed in the drinking water $(500 \mathrm{ng} / \mathrm{mL})$ and administered to the mice for 7 days.

X-ray irradiation: Mice were placed in a plastic holder at a distance of $50 \mathrm{~cm}$ from the X-ray source. $\mathrm{X}$-ray irradiation was performed using an X-ray unit (EXS-300-4, Toshiba Co., Tokyo, Japan) at a dose rate of $0.5 \mathrm{~Gy} / \mathrm{min}(200 \mathrm{kV}, 12 \mathrm{~mA})$. The beam was filtered through an $\mathrm{Al}$ filter $(1.0 \mathrm{~mm})$, and the dose rate was determined using ferrous ammonium sulfate dosimetry (11).

Collection of urine and serum samples: For urine collection, the mice were housed individually in glass metabolic cages (Sugiyama-Gen Iriki Co., Tokyo, Japan), and 24-h urine outputs were collected and stored at $-20^{\circ} \mathrm{C}$ until analyzed. The whole blood of the mice was collected from the vena cava inferior at $24 \mathrm{~h}$ after X-ray irradiation, under deep ether anesthesia. The serum was separated by centrifugation after clotting, and was stored at $-20^{\circ} \mathrm{C}$ until use.

Isolation of nuclear DNA: Mice were killed under deep ether anesthesia immediately or $24 \mathrm{~h}$ after X-ray irradiation, and the livers were promptly removed and stored at $-80^{\circ} \mathrm{C}$ until analyzed. The nuclear DNA of the mouse liver was isolated by the sodium iodide method, using a DNA Extraction WB Kit (Wako Pure Chemical Industries, Ltd., Osaka, Japan). To avoid oxidative DNA artifacts, $1 \mathrm{mM}$ desferal (deferoxamine mesylate, Sigma Chemical Co., MO, USA) was added to the lysis solution for the liver homogenization and DNA extraction. A fifty $\mathrm{mg}$ portion of liver was homogenized with a teflon-glass homogenizer, in $1 \mathrm{~mL}$ of ice-cold lysis solution. Subsequent DNA isolation was performed according to the manufacturer's instructions.

Analysis of 8-OH-dG in DNA: The isolated DNA was digested with 8 units of nuclease P1 (Yamasa Corp., Choshi, Japan) in $100 \mu \mathrm{L}$ of a solution containing $1 \mathrm{mM}$ EDTA and $20 \mathrm{mM}$ sodium acetate (pH 4.5). It was then treated with 2 units of alkaline phosphatase (Roche Diagnosis $\mathrm{GmbH}$, Mannheim, Germany) in $250 \mathrm{mM}$ Tris-HCl buffer (pH8.0), to obtain a deoxynucleoside mixture. The solution was filtered with an UltrafreeProbind filter (UFC 3IPH, Millipore, Bedford, MA). The filtrate was kept at $-80^{\circ} \mathrm{C}$ until analyzed. The filtrate was injected into an HPLC column (Capcell Pak C18 MG, $5 \mu \mathrm{m}, 4.6 \times 250 \mathrm{~mm}$, Shiseido Fine Chemicals, Tokyo, Japan) equipped with UV (UV-8020, Tosoh Co., Tokyo, Japan) and ECD (ECD-300, Eicom Co., Kyoto, Japan, applied voltage: $550 \mathrm{mV}$ ) detectors. The mobile phase was $10 \mathrm{mM} \mathrm{NaH} \mathrm{PO}_{4}$, containing $8 \%$ methanol and $0.13 \mathrm{mM} \mathrm{Na} 2$ EDTA, delivered at a flow rate of $1.0 \mathrm{~mL} / \mathrm{min}$. The column temperature was $32^{\circ} \mathrm{C}$. The amount of $8-\mathrm{OH}-\mathrm{dG}$ in the DNA was determined by comparison to the authentic standards. The 8-OH-dG value in the DNA was calculated as the number of $8-\mathrm{OH}-\mathrm{dG}$ per $10^{6}$ deoxyguanosine $(\mathrm{dG})$.

Analysis of 8-OH-dG in urine: Frozen urine samples were defrosted and mixed completely to form homogeneous suspensions. For the $8-\mathrm{OH}-\mathrm{dG}$ analysis, a $50 \mu \mathrm{L}$ aliquot of each sample was mixed with the same volume of a dilution solution, containing the ribonucleoside marker 8-hydroxyguanosine (120 $\mathrm{mg} / \mathrm{mL}$ ) and $4 \%$ acetonitrile in a solution of $130 \mathrm{mM}$ $\mathrm{NaOAc}(\mathrm{pH} 4.5)$ and $0.6 \mathrm{mM} \mathrm{H}_{2} \mathrm{SO}_{4}$. The diluted urine samples were centrifuged at $13,000 \mathrm{rpm}$ for $5 \mathrm{~min}$. A 70 $\mu \mathrm{L}$ aliquot of each supernatant was transferred to a vial for analysis in the apparatus.

Apparatus and 8-OH-dG analysis: The urinary 8$\mathrm{OH}-\mathrm{dG}$ level was determined using the detection apparatus, in which three pumps, the sampling injector, two valves, the HPLC-1 column, the UV detector, the HPLC-2 column, and the EC detector were connected. The HPLC-1 column was set in a column oven at $65^{\circ} \mathrm{C}$, and the HPLC- 2 column was set in a column oven at $50^{\circ} \mathrm{C}$. A $20 \mu \mathrm{L}$ aliquot of the diluted urine sample was injected into HPLC-1 (MCI GEL CA08F, $7 \mu \mathrm{m}, 1.5 \times$ $150 \mathrm{~mm}$, solvent $A, 50 \mathrm{~mL} / \mathrm{min}$ ) from the sampling injector, and the chromatogram was recorded by a UV detector $(245 \mathrm{~nm})$. In this method, the $8-\mathrm{OH}-\mathrm{dG}$ fraction was collected, depending upon the relative elution position from the peak of the added marker, 8-OH- 
Guo, and was automatically injected into the HPLC-2 column (Shiseido, Capcell Pak C18, $5 \mu \mathrm{m}, 4.6 \times 250$ $\mathrm{mm}$, solvent $\mathrm{B}, 1 \mathrm{~mL} / \mathrm{min}$ ). This column was coupled with an ECD (Coulochem III EC detector with a guard cell (5020) and an analytical cell (5011) (applied voltage: guard cell, $400 \mathrm{mV}$; E1, $280 \mathrm{mV}$; E2, $350 \mathrm{mV}$ ). The solvents used were: solvent $\mathrm{A}, 2 \%$ acetonitrile in 0.3 $\mathrm{mM}$ sulfuric acid; solvent $\mathrm{B}, 10 \mathrm{mM}$ sodium phosphate buffer ( $\mathrm{pH} 6.0), 5 \%$ methanol, plus an antiseptic, Reagent MB $(100 \mu \mathrm{L} / \mathrm{L})$.

Analysis of 8-OH-Gua in urine: Urine samples were mixed with the same volume of a dilution solution, containing AcG $(70 \mathrm{mg} / \mathrm{mL})$ and $4 \%$ acetonitrile in 130 $\mathrm{mM} \mathrm{NaOAc}(\mathrm{pH} 4.5)$ and $0.6 \mathrm{mM} \mathrm{H}_{2} \mathrm{SO}_{4}$, and were centrifuged, and each supernatant was injected into the apparatus. The 8-OH-Gua fraction was collected, depending upon the relative elution position from the peak of the added marker, AcG, and was automatically injected into the HPLC-2 column. For the analysis of 8-OH-Gua, an Eicom ECD-300 EC detector (applied voltage: $600 \mathrm{mV}$ ) was connected to HPLC-2, instead of the Coulochem III ECD. The conditions for HPLC-2 were as follows: mobile phase: $10 \mathrm{mM} \mathrm{NaH} \mathrm{PO}_{4}$ containing $5 \%$ methanol and $0.13 \mathrm{mM} \mathrm{Na} \mathrm{NaDTA}_{2}$; flow rate: $0.9 \mathrm{~mL} / \mathrm{min}$; column temperature: $20^{\circ} \mathrm{C}$.

Analysis of 8-OH-Gua in serum: The serum $(50$ $\mu \mathrm{L})$ was digested with proteinase $\mathrm{K}(10 \mu \mathrm{L}$ of $20 \mathrm{mg} / \mathrm{mL}$ solution, Sigma Chemical Co., MO, USA) at $37^{\circ} \mathrm{C}$ for $1 \mathrm{~h}$. The proteinase-digested serum was mixed with an equal volume $(60 \mu \mathrm{L})$ of a diluent containing AcG as a marker for column switching. After centrifugation at $13,000 \mathrm{rpm}$ for $5 \mathrm{~min}$, a $20 \mu \mathrm{L}$ aliquot of the supernatant was injected.

Analysis of 8-OH-Gua and 8-OH-dG in diets: To 3-10 mg samples of the CE-2 diet and the Egg white diet containing egg white as the protein source (Dyets no. 110952 ) were added $0.1 \mathrm{~mL}$ of water and $0.1 \mathrm{~mL}$ of the dilution buffer, and the samples were extracted for $3 \mathrm{~h}$ at $5^{\circ} \mathrm{C}$. After centrifugation at $13,000 \mathrm{rpm}$ for $5 \mathrm{~min}$, a $20 \mu \mathrm{L}$ aliquot of the supernatant was injected into the HPLC apparatus for the $8-\mathrm{OH}-\mathrm{Gua}$ or $8-\mathrm{OH}-\mathrm{dG}$ analysis. The amounts of these compounds shown are mean values of duplicate data.

Calculation of excretion/intake ratio after 8-OHGua, 8-OH-Guo and 8-OH-dG administration: Solutions of 8-OH-Gua, 8-OH-Guo and 8-OH-dG (500 $\mathrm{ng} / \mathrm{mL}$ ) were given to mice instead of water. On days 2 and 7, the amounts of intake and excretion of each compound were calculated, based on their concentration and the volumes of intake and excreted urine during $24 \mathrm{~h}$.

Statistical Analysis: Analyses were performed using the Stat View-J 5.0 program (SAS Institute, Cary, $\mathrm{NC}$, USA). The data are expressed as the mean $\pm \mathrm{SD}$ from three to four independent measurements. Statisti-
Table 1. Effect of storage temperature after DNA digestion on the artifactual formation of $8-\mathrm{OH}-\mathrm{dG}$

\begin{tabular}{ccc}
\hline \hline $\begin{array}{c}\text { Time after } \\
\text { sample preparation } \\
\text { (min) }\end{array}$ & \multicolumn{2}{c}{$8-\mathrm{OH}-\mathrm{dG} / 10^{6} \mathrm{dG}$} \\
$10^{\circ} \mathrm{C}$ & $-80^{\circ} \mathrm{C}$ \\
\hline 0 & 1.2 & 1.1 \\
40 & 1.2 & 1.0 \\
80 & 1.8 & 1.5 \\
120 & 2.4 & 1.2 \\
160 & 3.5 & 1.3 \\
\hline
\end{tabular}

Table 2. Amounts of $8-\mathrm{OH}-\mathrm{Gua}$ and $8-\mathrm{OH}-\mathrm{dG}$ in mouse diet $(\mathrm{pg} / \mathrm{mg})^{*}$

\begin{tabular}{ccc}
\hline \hline & 8-OH-Gua & $8-\mathrm{OH}-\mathrm{dG}$ \\
\hline Egg white diet & 6.59 & $\mathrm{ND}$ \\
CE-2 & 368 & 51 \\
\hline
\end{tabular}

ND: Not Detected.

*mean value of duplicate measurements.

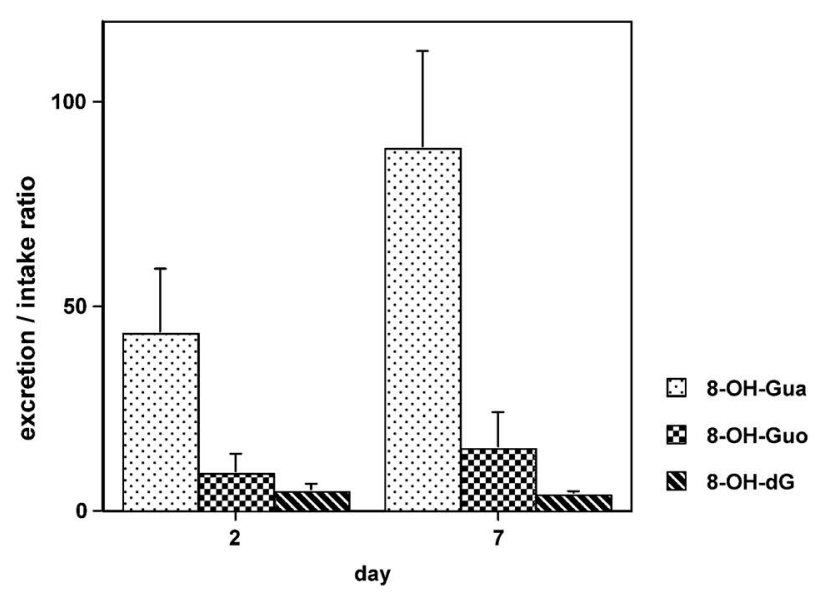

Fig. 1. Excretion/intake ratios of 8-OH-Gua, 8-OH-Guo and 8-OH$\mathrm{dG}$ on days 2 and 7 after starting their administration.

cal significance was determined by the Student's $t$-test, using $\mathrm{p}<0.05$ as the level of significance.

\section{Results}

Effects of storage temperature after DNA digestion on the artificial formation of 8-OH-dG: Kasai et al. (12) previously reported that the 8-OH-dG levels increased when a DNA digestion mixture was kept at $37^{\circ} \mathrm{C}$. We measured the $8-\mathrm{OH}-\mathrm{dG}$ levels of enzymehydrolyzed mouse liver DNA solutions that were kept at either $10^{\circ} \mathrm{C}$ or $-80^{\circ} \mathrm{C}$ prior to the HPLC analysis. The results of the $8-\mathrm{OH}-\mathrm{dG}$ analyses (single measurement) of these samples are shown in Table 1. Even with storage at a relatively low temperature $\left(10^{\circ} \mathrm{C}\right)$, significantly elevated levels of $8-\mathrm{OH}-\mathrm{dG}$ were detected, but 

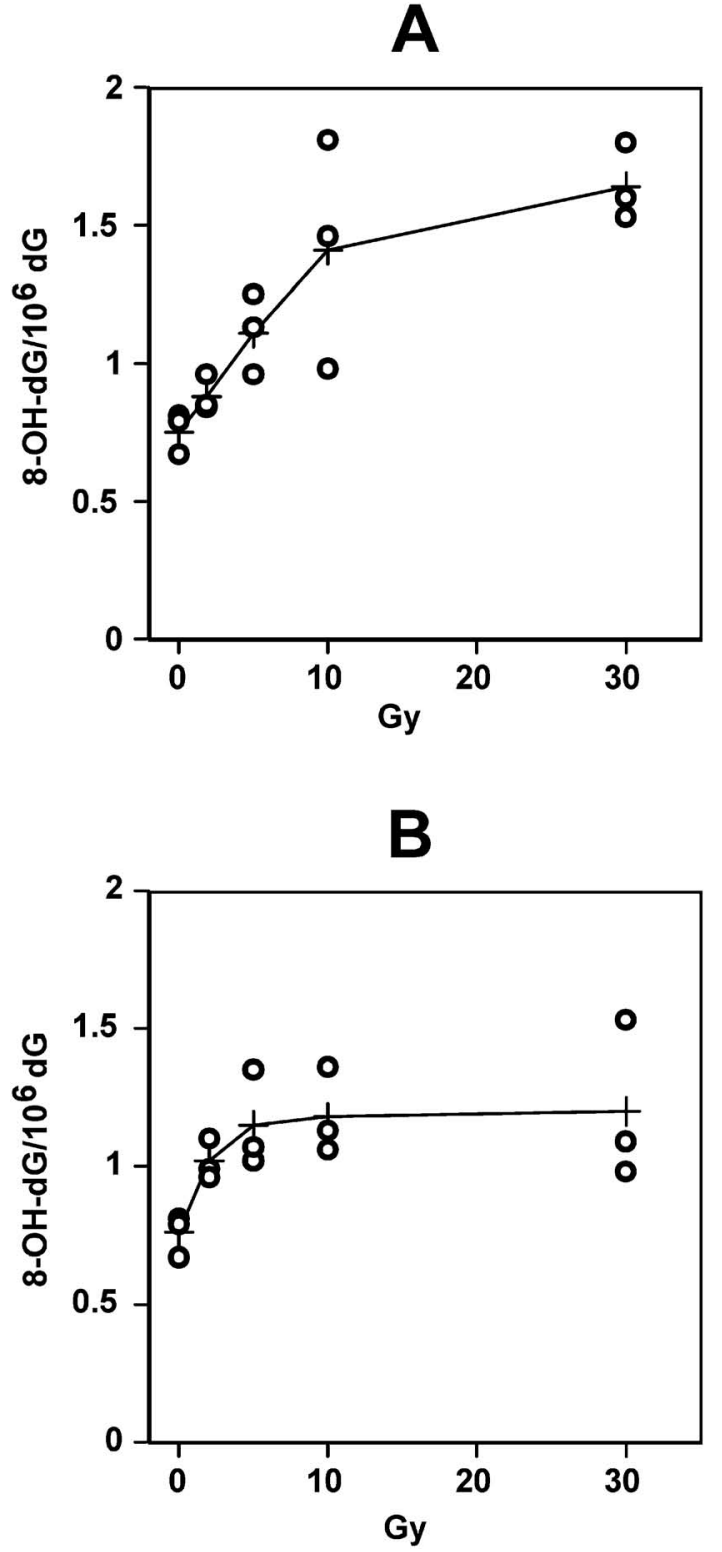

Fig. 2. 8-OH-dG levels in mouse liver DNA immediately (A) and $24 \mathrm{~h}$ (B) after X-ray irradiation. The line and the cross symbols represent mean values.

at $-80^{\circ} \mathrm{C}$, no change in the $8-\mathrm{OH}-\mathrm{dG}$ levels was observed.

8-OH-Gua and 8-OH-dG contents in mouse diets: High levels of 8-OH-Gua and a considerable amount of 8-OH-dG were detected in the CE-2 diet (Clea Japan. Inc., Tokyo), which is a commonly used laboratory rodent diet in Japan (Table 2). In comparison, a 50-fold lower level of 8-OH-Gua was detected in the Egg white diet, which contains egg white as the protein source. 8$\mathrm{OH}-\mathrm{dG}$ was not detected in the latter diet.

Excretion of orally administered 8-OH-Gua, 8-OHdG and 8-OH-Guo into urine: On days 2 and 7 after starting the 8-OH-Gua administration, the ratios of

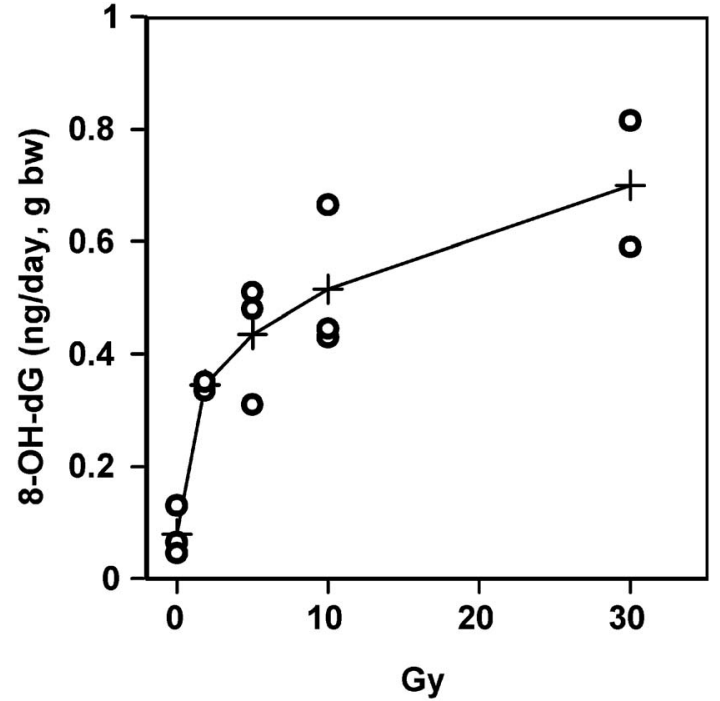

Fig. 3. Urinary $8-\mathrm{OH}-\mathrm{dG}$ levels during $24 \mathrm{~h}$ after $\mathrm{X}$-ray irradiation of mice. The line and the cross symbols represent mean values.

excretion to intake were 44 and $89 \%$ respectively (Fig. 1). In contrast, the excretion/intake ratios of 8$\mathrm{OH}-\mathrm{Guo}$ and $8-\mathrm{OH}-\mathrm{dG}$ were only $9-15$ and $4-5 \%$, respectively.

8-OH-dG content in nuclear DNA in X-ray irradiated mice: The data in Fig. 2A show that the level of 8-OH-dG in the DNA from the liver dose-dependently increased by X-ray irradiation from a dose of $2 \mathrm{~Gy}$. The $8-\mathrm{OH}-\mathrm{dG}$ level in the $2 \mathrm{~Gy}$ irradiated mouse DNA was 1.3-fold higher than that of the non-irradiated control mouse DNA $(0.76 \pm 0.08$ 8-OH-dG/106 dG). The 8-OH$\mathrm{dG}$ levels in the DNA decreased $24 \mathrm{~h}$ after irradiation at doses of 10 and 30 Gy (Fig. 2B).

Urinary 8-OH-dG levels of X-ray irradiated mice: The urinary level of $8-\mathrm{OH}-\mathrm{dG}$ was significantly increased by total body X-ray irradiation of mice (Fig. 3). The 8-OH-dG level was increased about 4.2 -fold by $2 \mathrm{~Gy}$ irradiation, from 0.08 to $0.35 \mathrm{ng} / \mathrm{day}$, g body weight. The tendency of the $8-\mathrm{OH}-\mathrm{dG}$ to increase by $\mathrm{X}$-ray irradiation continued up to $30 \mathrm{~Gy}$.

Analysis of 8-OH-Gua in urine and serum: We (13) previously described the analysis of urinary 8-OHGua. In recent experiments, we have found an improved marker, AcG, for the automatic peak recognition. It facilitates the precise measurement of $8-\mathrm{OH}-\mathrm{Gua}$ in urine, as shown in Fig. 4. The 8-OH-Gua peak was clearly separated. This remarkably accurate measurement method also allows us to detect very low levels of 8-OH-Gua in biological fluids, such as serum (Fig. 5). The $\mathrm{S} / \mathrm{N}$ ratio was sufficiently high to detect $8-\mathrm{OH}-\mathrm{Gua}$ in serum.

The mean level of urinary 8-OH-Gua in the control group was $1.38 \pm 0.51 \mathrm{ng} /$ day, g body weight. It increased to $2.62 \pm 0.45 \mathrm{ng} /$ day, g body weight (1.9-fold 

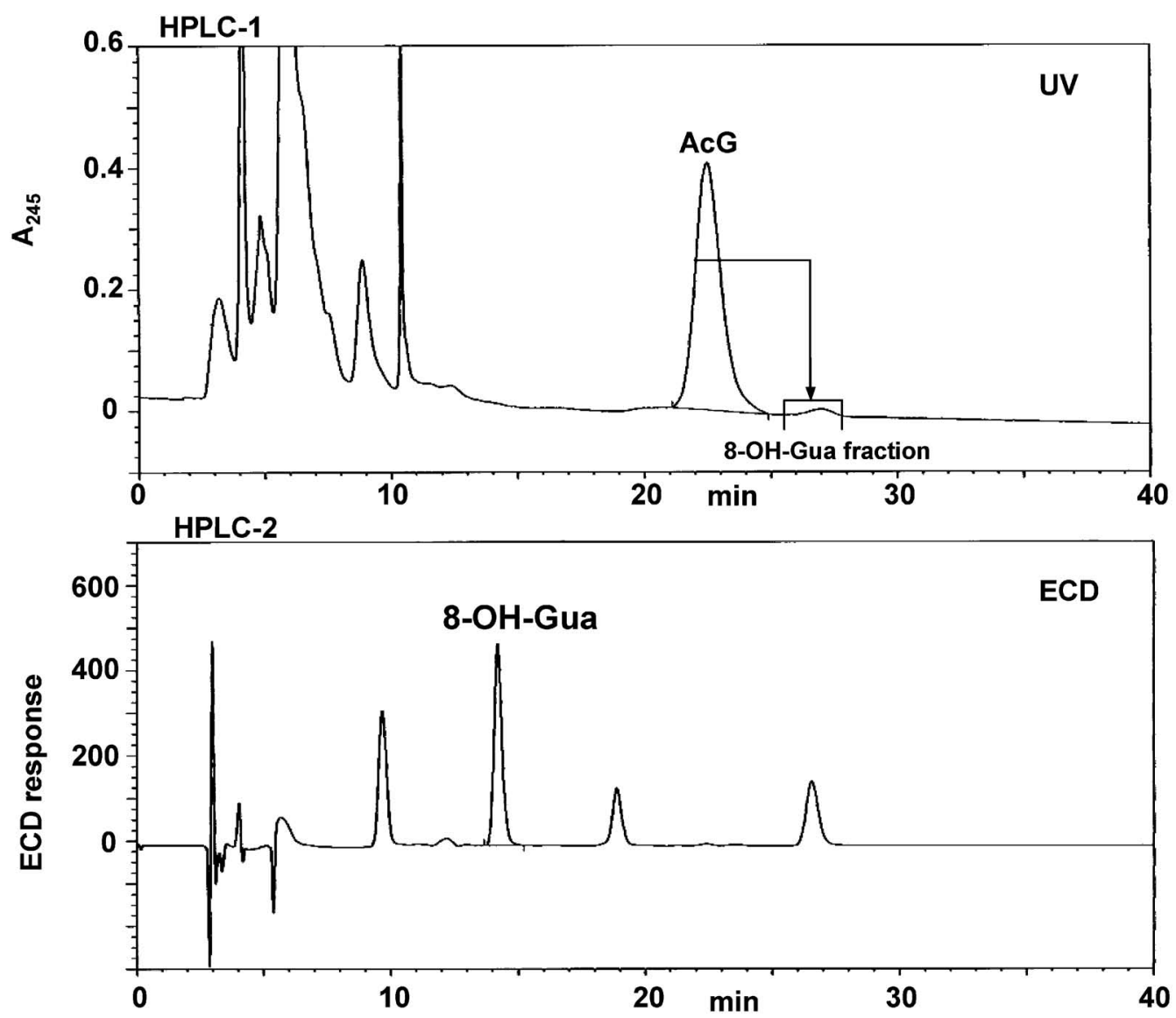

Fig. 4. Analysis of 8-OH-Gua in mouse urine by two step-HPLC. Detection of the AcG marker and collection of the 8-OH-Gua fraction in anion exchange chromatography (HPLC-1), and analysis of 8-OH-Gua by reverse-phase HPLC (HPLC-2).

higher than the control) by 2 Gy of total body irradiation (Fig. 6). The urinary level of 8-OH-Gua increased dose-dependently with X-ray irradiation up to $10 \mathrm{~Gy}$.

The serum 8-OH-Gua concentration was $0.11 \pm 0.03$ $\mathrm{ng} / \mathrm{mL}$ in the control mice. Total body X-ray irradiation significantly increased the serum $8-\mathrm{OH}$-Gua level in a dose-dependent manner up to $10 \mathrm{~Gy}$ of irradiation (Fig. 7).

\section{Discussion}

It is important to measure 8-OH-dG in cellular DNA accurately and with high reproducibility. In this study, we found that the storage of the DNA digestion mixture at $10^{\circ} \mathrm{C}$ for $2 \mathrm{~h}$, caused the $8-\mathrm{OH}-\mathrm{dG}$ levels to increase 2 -fold. The digested DNA samples should be kept at $-80^{\circ} \mathrm{C}$ until immediately before the HPLC analysis. Therefore, the sequential injection of many samples kept in an auto-injector during the day is not recommended for 8-OH-dG analysis.

For the accurate measurement of urinary $8-\mathrm{OH}-\mathrm{Gua}$ and $8-\mathrm{OH}-\mathrm{dG}$, we initially examined these compounds in the diet, since particles of the diet may contaminate the urine sample in the metabolic cage during the $24 \mathrm{~h}$ urine collection. We confirmed the presence of 8-OHGua and 8-OH-dG in the laboratory rodent diet CE-2. The source of these compounds in the diet may be the fish powder used to prepare the diet, because we previously determined that fish products contain 8-OHGua, 8-OH-dG and 8-OH-Guo (14). The 8-OH-Gua levels in commercial rodent diets containing wheat gluten, soy protein and egg white as protein sources showed low levels of 8-OH-Gua (data not shown). Among them, the egg white diet contained the lowest level of 8-OH-Gua.

The second question addressed is whether the 8-OHGua compounds in the diet are excreted into the urine after oral administration, or are decomposed in the digestive tract. It is important to clarify this point, because when these markers are used for human biomonitoring, variations in the content of $8-\mathrm{OH}-\mathrm{Gua}$ compounds in different diets may affect their background levels in urine. The aqueous solutions of $8-\mathrm{OH}-$ Gua, 8-OH-dG and 8-OH-Guo were provided to the mice, instead of water, and the urinary levels of these compounds were monitored by HPLC-ECD. The excretion/intake ratio of each compound into urine was 

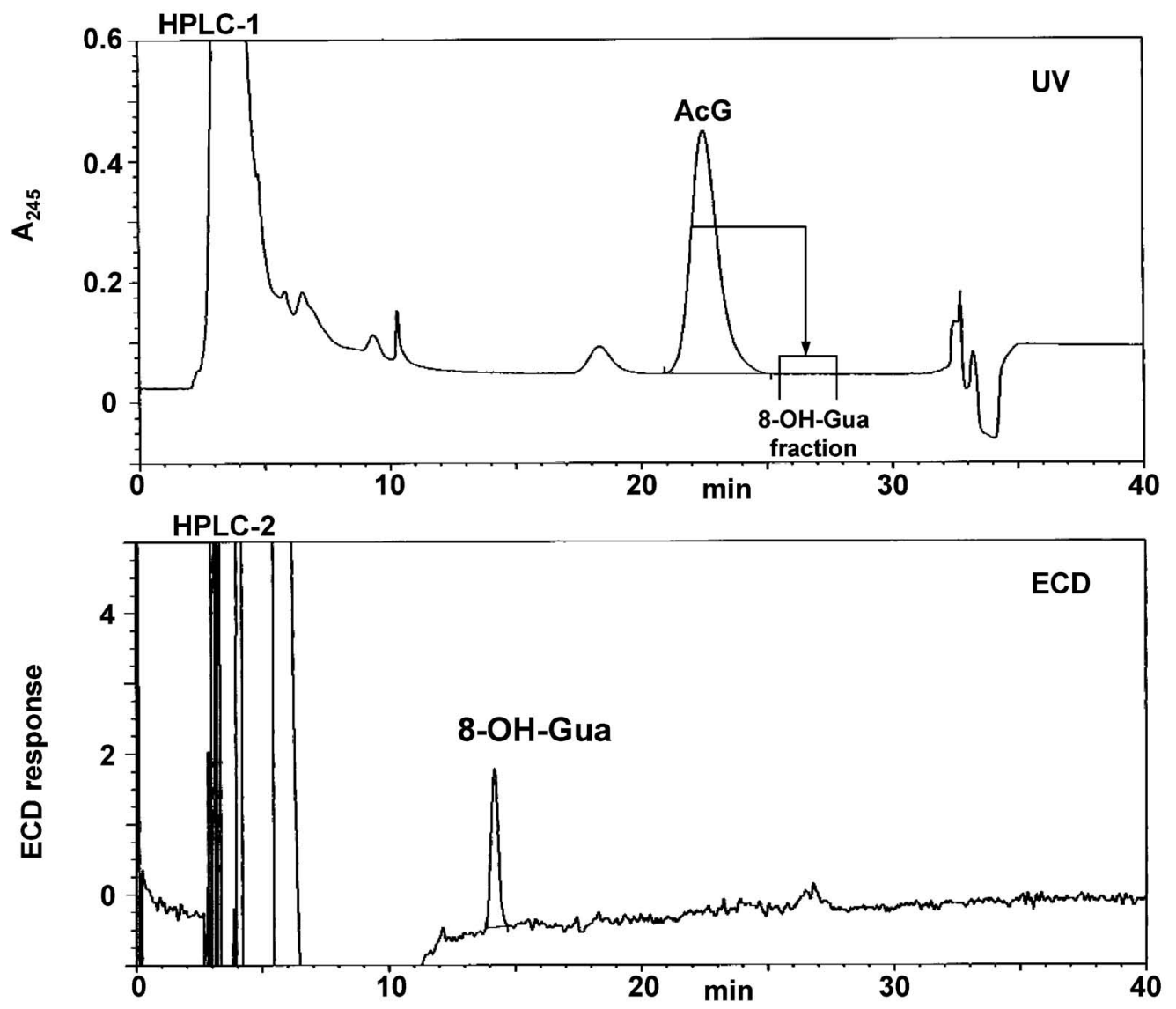

Fig. 5. Analysis of 8-OH-Gua in mouse serum by two step-HPLC. Detection of the AcG marker and collection of the 8-OH-Gua fraction in anion exchange chromatography (HPLC-1), and analysis of 8-OH-Gua by reverse-phase HPLC (HPLC-2).

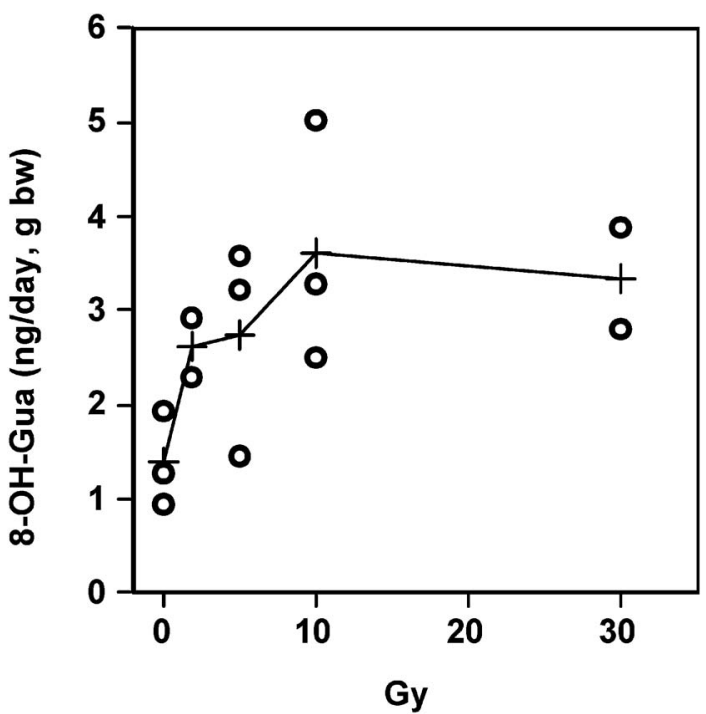

Fig. 6. Urinary 8-OH-Gua levels during $24 \mathrm{~h}$ after X-ray irradiation of mice. The line and the cross symbols represent mean values.

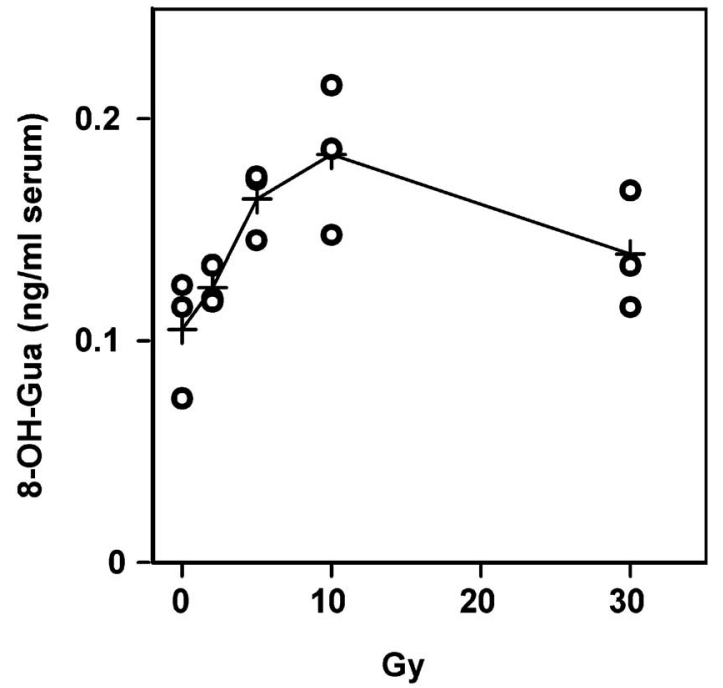

Fig. 7. Serum 8-OH-Gua levels $24 \mathrm{~h}$ after $\mathrm{X}$-ray irradiation of mice. The line and the cross symbols represent mean values. 
calculated (Fig. 1). We found that about $90 \%$ of the administered 8-OH-Gua was excreted into the urine on day 7 , while the excretion/intake ratios of $8-\mathrm{OH}-\mathrm{Guo}$ and $8-\mathrm{OH}-\mathrm{dG}$ were $9-15 \%$ and $4-5 \%$, respectively. Most of the administered 8-OH-dG and 8-OH-Guo was probably decomposed or catabolized to other compounds. These data suggest that $8-\mathrm{OH}-\mathrm{dG}$ is a useful biomarker of oxidative stress, irrespective of the intake level from the diet.

On the other hand, because the dietary intake of 8$\mathrm{OH}-\mathrm{Gua}$ influences its urinary level, its utility as a biomarker in human studies should be limited. However, in animal experiments using a nucleic acidfree diet, such as the egg white diet, 8-OH-Gua can be analyzed as a useful marker of oxidative stress.

By these improvements of the analysis methods and the diet, the best conditions for the animal experiments were established. Using these conditions, we tested the effect of X-ray irradiation on mice. After the mice were irradiated with 2-30 Gy X-rays, at a dose rate of 0.5 $\mathrm{Gy} / \mathrm{min}$, the urinary 8-OH-dG and 8-OH-Gua, the serum $8-\mathrm{OH}-\mathrm{Gua}$, and the $8-\mathrm{OH}-\mathrm{dG}$ in the liver DNA were measured. Among these markers, the urinary 8$\mathrm{OH}-\mathrm{dG}$ collected during $24 \mathrm{~h}$ was most dramatically increased by low dose X-ray irradiation (Fig. 3). After irradiation with $2 \mathrm{~Gy} \mathrm{X}$-ray, the excretion of $8-\mathrm{OH}-\mathrm{dG}$ increased 4-fold. The level of 8-OH-dG in the liver DNA was also dose-dependently increased by X-ray irradiation. Significant increases in urinary and serum $8-\mathrm{OH}-$ Gua were also detected after irradiation with 2-10 Gy $\mathrm{X}$-ray. All of these data support the suggestion that both $8-\mathrm{OH}-\mathrm{dG}$ and the free base, $8-\mathrm{OH}-\mathrm{Gua}$, are useful markers of oxidative stress.

A Swedish group reported that urinary $8-\mathrm{OH}-\mathrm{dG}$ increased after whole body irradiation (Total dose, 12 Gy during 4 days) of leukemia patients (15). The urinary levels of $8-\mathrm{OH}-\mathrm{dG}$ differed significantly between the patients. A correlation between the excreted levels of $8-\mathrm{OH}-\mathrm{dG}$, one of the repair products, and the radiosensitivity was suggested, and thus, in the future, it may be used as a predictive assay for each patient prior to radiotherapy.

The sources of urinary 8-OH-dG include: 1 ) its formation from 8-OH-dGTP by the action of the MTH1 nucleotide sanitization enzyme and subsequent digestion by a $5^{\prime}\left(3^{\prime}\right)$-nucleotidase, and 2 ) the nucleotide excision type repair (NER) of oxidized DNA. On the other hand, the sources of the free base $8-\mathrm{OH}-\mathrm{Gua}$ in urine and serum are the base excision type repair of oxidized DNA, and the oxidation of guanine formed by the hydrolytic degradation of DNA, RNA and nucleotides.

In the present study, we established the best conditions to analyze 8-OH-Gua compounds as biomarkers for oxidative stress. Using these conditions, one can correctly assess oxidative stress in animal experiments and human studies. For example, for a human study, the analysis of urinary 8-OH-dG is an ideal marker, because it is not affected by the diet. For animal experiments, urinary 8-OH-dG is also the best marker, if the mice are fed an egg white diet. Urinary and serum 8$\mathrm{OH}-\mathrm{Gua}$ may also be good markers with this diet condition. Analyses of these 8-OH-Gua compounds may be useful for studies on environmental mutagens that generate ROS, and for determining the in vivo effects of antioxidants, particularly in animal experiments. These biomarkers may also be useful in human populations, for risk estimation of lifestyle-related diseases involving ROS, including cancer, predictive assays for radiotherapy, and intervention studies for health promotion via the diet.

Acknowledgements: This work was supported by Grants-in-Aid from the Ministry of Education, Culture, Sports, Science and Technology of Japan and the Ministry of Health, Labor and Welfare of Japan. The authors are grateful to Ms. Sayumi Yamasaki for excellent technical assistance.

\section{References}

1 Kasai H. Analysis of a form of oxidative DNA damage, 8-hydroxy-2'-deoxyguanosine, as a marker of cellular oxidative stress during carcinogenesis. Mutation Res. 1997; 387: 147-63.

2 Shigenaga MK, Gimeno CJ, Ames BN. Urinary 8hydroxy-2'-deoxyguanosine as a biological marker of in vivo oxidative DNA damage. Proc Natl Acad Sci USA. 1989; 86: 9697-701.

3 Witherell HL, Hiatt RA, Peplogle M, Parsonnet J. Helicobacter pylori infection and urinary excretion of 8 hydroxy-2'-deoxyguanosine, an oxidative DNA adduct. Cancer Epidemiol. Biomarkers Prev. 1998; 7: 91-6.

4 Cooke MS, Singh R, Hall GK, Mistry V, Duarte TL, Farmer PB, Evans MD. Evaluation of enzyme-linked immunosorbent assay and liquid chromatographytandem mass spectrometry methodology for the analysis of 8-oxo-7,8-dihydro-2'-deoxyguanosine in saliva and urine. Free Radic Biol Med. 2006; 41: 1829-36.

5 Shimoi K, Kasai H, Yokota N, Toyokuni S, Kinae N. Comparison between high-performance liquid chromatography and enzyme-linked immunosorbent assay for the determination of 8-hydroxy-2'-deoxyguanosine in human urine. Cancer Epidemiol Biomarkers Prev. 2002; 11: 767-70.

$6 \mathrm{Hu} \mathrm{CW}, \mathrm{Wu} \mathrm{MT}$, Chao MR, Pan $\mathrm{CH}$, Wang CJ, Swenberg JA, Wu KY. Comparison of analyses of urinary 8-hydroxy-2'-deoxyguanosine by isotope-dilution liquid chromatography with electrospray tandem mass spectrometry and by enzyme-linked immunosorbent assay. Rapid Commun Mass Spectrom. 2004; 18: 505-10.

7 Yoshida R, Ogawa Y, Kasai H. Urinary 8-oxo-7,8dihydro-2'-deoxyguanosine values measured by an ELISA correlated well with measurements by high-perfor- 
mance liquid chromatography with electrochemical detection. Cancer Epidemiol Biomarkers Prev. 2002; 11: 1076-81.

8 Park EM, Shigenaga MK, Degan P, Korn TS, Kitzler JW, Wehr CM, Kolachana P, Ames BN. Assay of excised oxidative DNA lesions: isolation of 8-oxoguanine and its nucleoside derivatives from biological fluids with a monoclonal antibody column. Proc Natl Acad Sci USA. 1992; 89: 3375-9.

9 Gackowski D, Rozalski R, Roszkowski K, Jawien A, Foksinski M, Olinski R. 8-Oxo-7,8-dihydroguanine and 8-oxo-7,8-dihydro-2'-deoxyguanosine levels in human urine do not depend on diet. Free Radic Res. 2001; 35: 825-32.

10 Ikehara M, Tada H. Muneyama K. Synthesis of 8hydroxypurine. Chem Pharm Bull. 1965; 13: 1140-2.

11 Fricke H, Hart EJ. Chemical dosimetry. In: Radiation Dosimetry. 2nd ed., vol.2. Attix FH, Roesch WC, editor. Academic Press (NY): pp. 167-239; 1966.
12 Kasai H, Crain PF, Kuchino Y, Nishimura S, Ootsuyama A, Tanooka H. Formation of 8-hydroxyguanine moiety in cellular DNA by agents producing oxygen radicals and evidence for its repair. Carcinogenesis. 1986; 7: 1849-51.

13 Svoboda P, Maekawa M, Kawai K, Tominaga T, Savela $\mathrm{K}$, Kasai H. Urinary 8-hydroxyguanine may be a better marker of oxidative stress than 8-hydroxydeoxyguanosine in relation to the life spans of various species. Antioxid Redox Signal. 2006; 8: 985-92.

14 Kawai K, Svoboda P, Kasai H. Detection of genotoxic nucleosides, 8-hydroxydeoxyguanosine, 8-hydroxyguanosine and free base 8-hydroxyguanine in fish food products. Genes Environ. 2006; 28: 120-2.

15 Tagesson C, Kallberg M, Klintenberg C, Starkhammar H. Determination of urinary 8-hydroxydeoxyguanosine by automated coupled-column high performance liquid chromatography: A powerful technique for assaying in vivo oxidative DNA damage in cancer patients. Eur $\mathrm{J}$ Cancer. 1995; 31A: 934-40. 